\title{
COVID-19 PANDEMIC AND WELFARE OF FISHERMEN KAMAL MUARA
}

\author{
Amanah Abdulkadir \\ Singaperbangsa University, Indonesia \\ Wendra Afriana \\ IPB University, Indonesia \\ Email: weiyacb@gmail.com \\ Harry Azhar Azis \\ Airlangga University, Indonesia
}

\begin{abstract}
This paper aims to find out the right and fast strategy in anticipating the decline in the welfare of fishermen Kamal Muara during the Covid-19 pandemic. The research used SAST, AHP, and ISM analysis methods. Based on the results of ISM processing, it shows that the most appropriate and quick strategy is, First, provide subsidies for fishermen's losses due to large-scale social restrictions (PSBB). Second, providing training programs for processing derivative products and training on sales digitization. Third, with digital marketing training to optimize the marketing of their fish catch while ensuring the safety of anglers at work. The government's role, in this case, is not only in budget allocation but also fosters and assists so that anglers can be adaptive to technology in every fishing activity.
\end{abstract}

\section{Keywords: Covid-19 Pandemic, Welfare, SAST, AHP}

Received: 1 October 2021 ;

Accepted: 24 December 2021 ;

Publish: December 2021

\section{How to Cite:}

Abdulkadir, A., et.al. (2021). Covid-19 Pandemic and Welfare of Fishermen Kamal Muara. Journal of Business and Behavioural Entrepreneurship, 5(2), 32-40. https:// doi.org/10.21009/JOBBE.005.2.05 


\section{INTRODUCTION}

The implementation of Large-Scale Social Restrictions (PSBB) to suppress the spread of the coronavirus causes limited movement of people and goods. As a result, the marketing or distribution chain is interrupted. One of the sectors affected is fisheries.

The COVID-19 pandemic has affected the sustainability of fishery product production and marketing activities in the fisheries sector. A total of 26,675 Fishery Households (RTP) were affected by COVID-19 because of the falling fish prices and closed marketing for exports (Efrizal, 2020). In addition, the policy of closing several areas also affects the absorption of fishery production by fishers. Fishers in some areas have difficulty selling fish and getting a fair price (Ranny, 2020)

The prices of caught fish have decreased, causing fishermen's income to decrease. Not to mention, closures in several areas have caused the fish supply chain to be more or less disrupted (Mardhia et al., 2020).

More than $80 \%$ of Indonesian fishers are small-scale fishermen who depend on fishing for their livelihood. Research by Bennett et al. (2020) revealed that the negative impact of the pandemic has implications for small-scale fishermen, such as stopped fishing, fisherman's health risks, disrupted market access, and increased illegal fishing.

Another problem is that when the fish distribution chain is disrupted, coastal areas that do not have cold storage to store fish will suffer a heavy impact. The fish caught are wasted or sold at very low prices to intermediaries.

Another impact of the pandemic is also targeting the children of fishers. Not all coastal areas and small islands have good access to electricity and internet access. Currently, schools are implementing distance learning where electricity and the internet are the main supports (Anta, 2020).

The pandemic has also had a significant impact on the welfare of fishers. It is recorded that in 2017, as many as 2.7 million fishermen in Indonesia contributed to 25 percent of the national poverty rate. The majority of anglers live on the threshold of the poverty line. Other data also states that about 53 percent of families in coastal areas live below the poverty line. This description is certainly a specific characteristic of the vulnerability of fishers and cultivators in the socio-economic context, especially in dealing with the current Covid-19 (Knti, 2020).

Furthermore, the Covid-19 pandemic has made it difficult for Kamal Muara anglers to find the money. The reason is, the fish they catch are priced very cheaply by traders at auction (Accurate, 2020). Not only that, before the pandemic, fisherman Kamal Muara also faced several problems that resulted in a decrease in fishermen's income. As a result, their welfare also decreased. These problems are caused, among others, due to reduced fishery resources caused by heavy metal contamination of $\mathrm{Ni}$ and $\mathrm{Pb}$ (Sindern 2016 in Robin, 2018), acute eutrophication of PO4 $4 \mathrm{~m} / \mathrm{L}$ (Baum et al. 2015), dissolved inorganic nutrients reaching $21 \mathrm{~m} / \mathrm{L}$ ( Ladwig et al., 2016 in Robin, 2018) as well as the conversion of coastal functions due to the reclamation of Jakarta Bay which has eliminated most of the fishing grounds (Sampono, 2013 in Robin, 2018). According to Ramadhan et al. (2016 in Robin, 2018), the potential loss of fishers from territorial waters reaches Rp. 94,714,228,734 per year, the loss of shellfish cultivators is Rp. $98,867,000,591$ per year, the loss of fish cultivators in ponds is Rp. $13,572,063,285$ per year.

Therefore, this paper will specifically examine how appropriate and quick strategies are in anticipating the decline in the welfare of Kamal Muara fishers during 
the Covid-19 pandemic, given that fishers dominate the population of Kamal Muara. It is shown in the research results of Robin et al. (2018) that in Kamal Muara, 81\% of respondents work as fishermen, $17 \%$ as traders, while in Muara Angke, 93\% of the respondents' main jobs are fishermen, and $7 \%$ are traders.

\section{RESEARCH METHODS}

The research uses a systems approach which is carried out in stages, namely (1) observation and literature study to determine the location and scope of research, (2) case studies at the specified location to obtain empirical data and expert surveys to acquire knowledge of thinking respondents by purposive sampling (Cooper and Schindler, 2008). The expert survey stage was carried out through in-depth interviews (IDI) and focused discussions (FGD) and filling out questionnaires for SAST, AHP, and ISM analysis.

The first step is to evaluate the main causes of the decline in the welfare of the fishing community of Kamal Muara. Then after knowing these factors, it is necessary to formulate strategic priorities in anticipating the decline in the welfare of the fishing community of Kamal Muara, after which the program mapping will be carried out first.

\section{RESULTS AND DISCUSSIONS}

\section{MITIGATION ACTION}

Based on the results of the FGD conducted with the KKP, relevant agencies from the provincial government, representatives of the North Jakarta HNSI, and the fishing community of Kamal Muara obtained 8 basic assumptions for development policies. The eight assumptions will be processed using the SAST technique to obtain the assumptions that are considered the most important and certain to be used in anticipating the decline in the welfare of the Kamal Muara community.

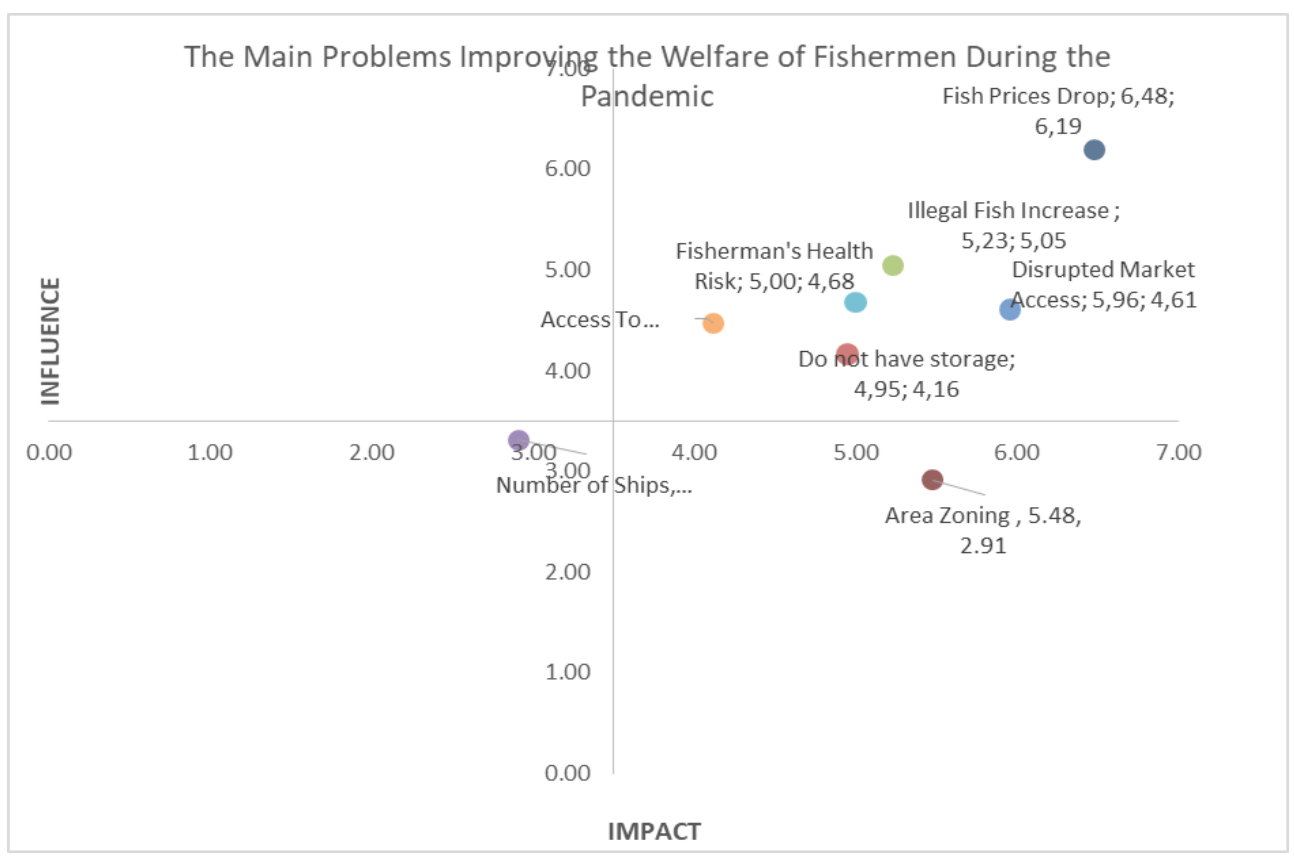


Figure 1: Ranking of Strategic Assumptions with the SAST Technique

Based on the results of the SAST analysis in Figure 1, there are six assumptions out of eight assumptions that are included in the most certain and most important quadrant, with the order of the highest positions being:

1. Fish prices drop

2. Illegal fishing increases

3. fisherman's health risk

4. Market access is disrupted

5. access to education for fishermen's children

6. have no cold storage

To achieve the goal of anticipating a decline in the welfare of the Kamal Muara community, stakeholders must pay attention to these strategic assumptions

as a driving force for its success. The six assumptions obtained from the SAST are the necessary conditions for designing a policy model using the AHP method.

Figure 2 shows the hierarchy of anticipated declines in the welfare of the fishing community of Kamal Muara and the criterion dependency relationship. Each criterion of anticipating a decline in welfare is interrelated. Therefore, to assess the importance of each criterion, the AHP method should be used. In the application of AHP, a level of dependence between criteria is required, a degree of dependence between criteria is required.

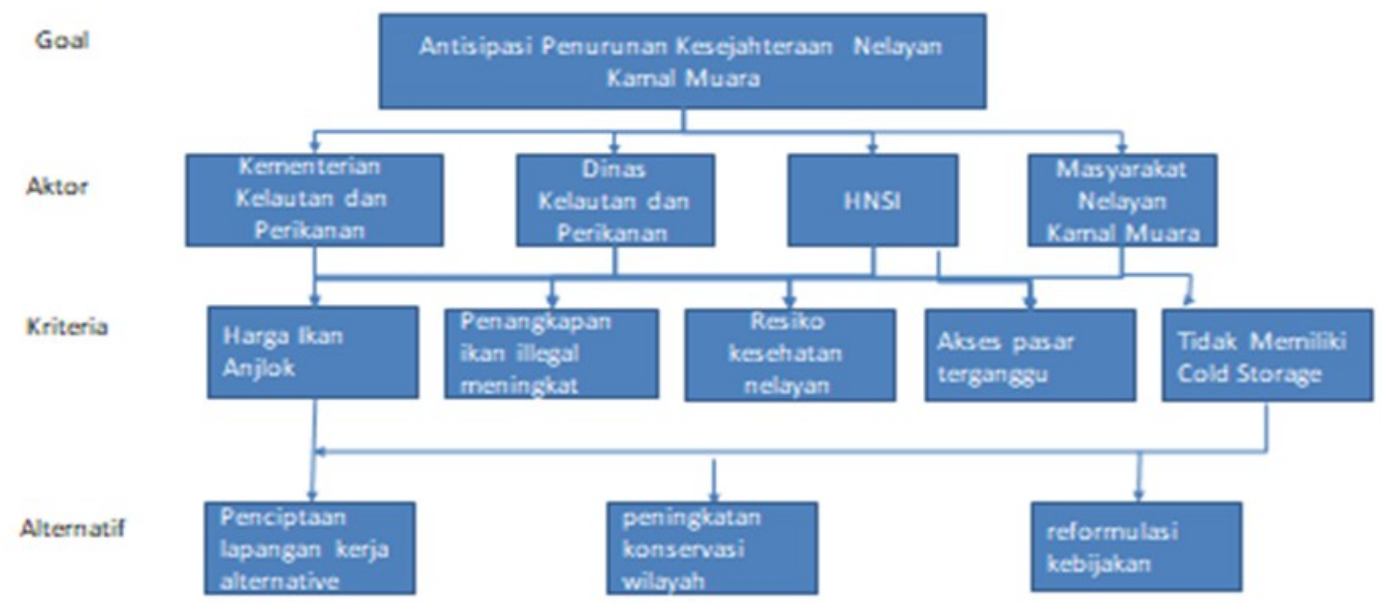

Figure 2 Main Problems Improving the Welfare of Fisherman Kamal Muara during the Pandemic

The decision-maker assesses the importance of each criterion based on certain control criteria. The results of this assessment will be processed using software that can accommodate the AHP model to produce an assessment weight that shows the best anticipation in reducing the decline in the welfare of the Kamal Muara community. 


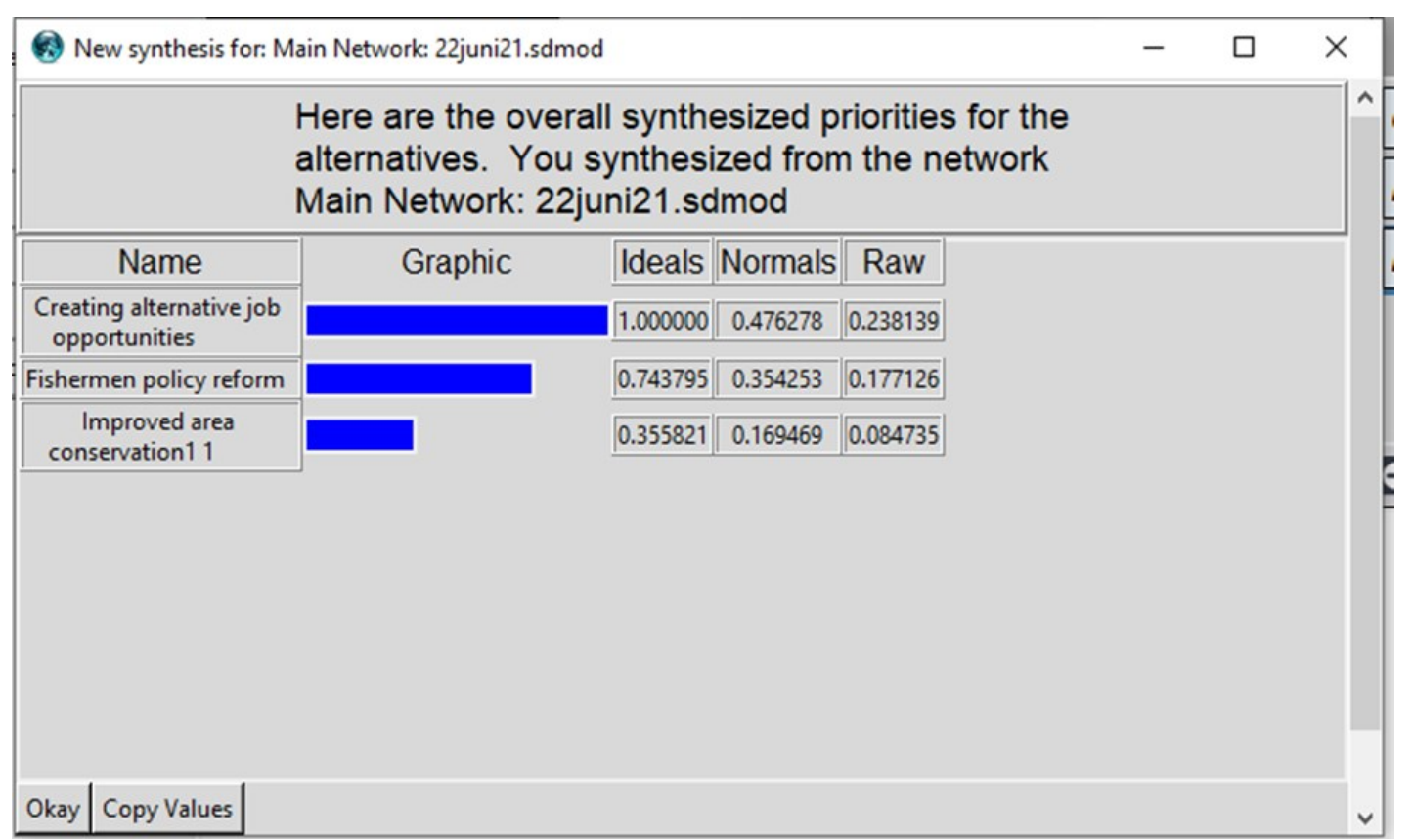

Figure 3. Synthesized Priorities

Based on Figure 3, the results of the priority scale that are synthesized for alternatives are obtained, which are the best alternatives to realize the research goals/ objectives to anticipate the decline in the welfare of Kamal Muara fishers during the pandemic, with the most important order being:

1. Creating alternative job opportunities $(48 \%)$

2. Fishermen policy reform (35\%)

3. Improved area conservation $(17 \%)$

Creating alternative employment outside of fishing has the highest weight (0.476). A side job or relying only on fishing activities is expected to be an added value for fishermen's families. Thus, if there is a case where fish catches are low, side jobs can help cover the daily needs of fishermen's families. And, if you catch a lot of fish, this side job can also increase your income so you can save money or buy other necessities.

Several studies have shown that the strategy used by fishermen to survive with minimal income and full of uncertainty is with side work (Asis, 2019; Listyawati, 2016). For this reason, it is necessary to formulate policies that are truly in favor of anglers so that they will have an impact on improving the welfare of fishers. Fisher's policy reformulation has the second-highest weighting score (0.354).

Final weighting score 0.169 for increased area conservation. Conservation is currently a demand and needs that must be met after reclamation. It is based on harmonizing the community's economic needs with the desire to conserve existing resources for the future. It confirms that nature conservation is not only to preserve the environment but also to improve the welfare of the people around the conservation area. The research results corroborate it by Riany et al. (2015); based on the results of ecological and economic evaluations, it can be concluded that the conservation area on the east coast of Pulau Weh can be very useful in maintaining ecosystems and fish stocks. Still, it is necessary to improve the quality of livelihoods to improve economic conditions. 
Furthermore, to create alternative employment opportunities, the government and society must, of course, carry out several programs so that these goals can be achieved. However, given the time, it is necessary first to determine the priority scale of which program will be implemented. It can be known with the ISM software.

Based on the results of discussions with experts and the community as objects in the field. The results of processing using the ISM software (figure 4) show that the first program that the government must carry out is to provide subsidies for fishermen's losses due to the large-scale social restriction (PSBB) policy which has had a huge impact. The government must be present for the fishermen of Kamal Muara so that they do not fall into the cycle of poverty. The second program is with regulations that regulate the prohibition of certain fishing tools and methods. The two programs must synergize with each other, considering that the government must be present for the welfare of the entire community, and its presence must also be oriented towards legal justice and welfare. Law exists not only to guarantee legal certainty but also to bring prosperity to all Indonesian people.

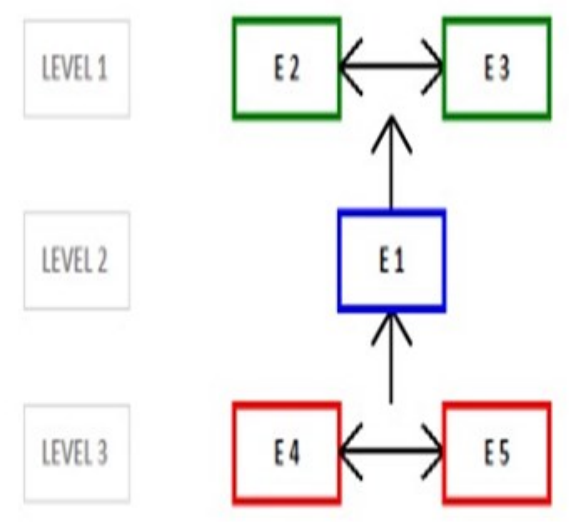

Figure 4 ISM Structure

Furthermore, if the program has been implemented well, then the program's continuation that can be carried out is to conduct training in environmentally friendly fishing. The results of Arafat's research (2018) state that without an effort to reconstruct fishing gear, the policies made will not benefit the sustainability of fishery resources and traditional fishers. Reconstruction of fishing gear here means the transition from destructive fishing gear to environmentally friendly fishing gear. Without mitigation from the government regarding the transition of fishing gear, several fishermen will not go to sea and lose their livelihoods. The subsequent impact, of course, on the welfare of anglers and their families.

Furthermore, the programs that must be carried out are training on processing derivative products and digitizing sales. These two programs are essential, especially in the industrial era 4.0. Fish and other fishery products are perishable foodstuffs, partly due to microbiological degradation and enzyme activity. Processed fish production $23-47 \%$; the remainder is sold fresh or exported. Traditional processing methods are more dominant than modern methods. 
For this reason, training on food processing based on fishery products can be marketed to increase the selling value of fishers. Not only processing but in the industrial era 4.0 , anglers must also be smart in marketing the processed products to buyers. See the matrix values in the highest and lowest columns; it can be seen in Figure 6.

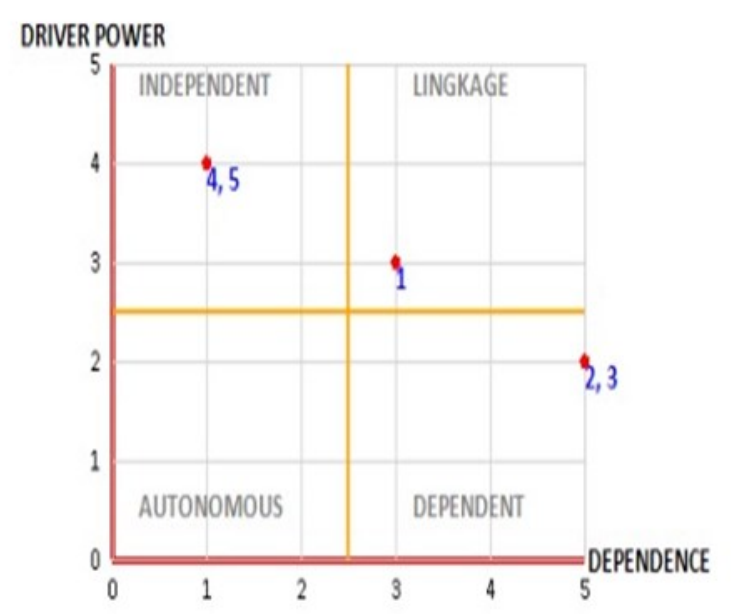

Picturer 5. Matriks driving power (DP) dan dependence (D)

Sector or Quadrant I: Autonomous, no sub-elements

Quadrant II: Dependent there are sub-elements 2 and 3

Quadrant III: Lingkage has sub element 1

Quadrant IV: Independent there are sub-elements 4 and 5

Figure 5 is grouped by driving power (DP) and dependence (D) which consists of 5 (nine) sub-elements. The picture shows that 1 sub-element, namely environmentally friendly fishing training is in the linkage. Dependent 2 (two) subelements, namely training on processing derivative products and training on sales digitization. While independent, there are 2 sub-elements, namely subsidies for fishermen's losses and regulations that regulate the prohibition of the use of certain fishing tools and methods. While autonomous, there are no sub-elements.

Based on the value of driving power and dependence, the DP-D matrix is obtained, at

There are subsidies for fishermen's losses and regulations governing the prohibition of certain fishing tools and methods in the independent sector, meaning that the government's role in the driving force is strong. However, dependence on other systems is still weak. While in the dependent sector, there are 2 (two) sub-elements, namely training on processing derivative products and training on digitizing sales. That is, the driving force is weak, but the dependence on other systems is strong. The impetus for processing derivative products and selling products can be done digitally. However, there is still a shortage of human resources who train, so they strongly depend on other systems to provide such training to fishers. In the linkage sector, there is one sub-element, namely environmentally friendly fishing training. This means that these sub-elements have an important role in all fishing activities. 


\section{CONCLUSION}

Based on the results of the ISM processing that have been described previously, that the most appropriate and quick strategy to be able to help the welfare of the fishermen of Kamal Muara does not decrease during this pandemic, the first in the program to provide subsidies for fishermen's losses due to large-scale social restrictions (PSBB). This subsidy can be done in the form of providing subsidized fuel for the fishermen of Kamal Muara and optimizing the operation of the fishermen's public fueling station. This was done to encourage the fishermen of Kamal Muara to be more productive. The welfare of the fishermen of Kamal Muara did not decrease, although there was an insignificant decline.

After the program is well implemented, the next step is to provide a training program for processing derivative products and digitizing sales. This strategy can be done by implementing a diversified adaptation strategy. This diversification strategy is important because fishery commodities are perishable or perishable commodities and do not last long if stored intact. For this reason, training on derivative products is intended to minimize the level of damage to fishery products by diversifying processed products that are more durable but still have a stable selling value. Furthermore, digital marketing can optimize the marketing of their fish catch while ensuring the safety of anglers at work. The government's role, in this case, is not only in budget allocation but also fosters and assists so that anglers can be adaptive to technology in every fishing activity.

\section{REFERENCE}

Abdul asis. (2019). Strategi Bertahan Hidup Nelayan Karampuang Dalam Pemenuhan Kebutuhan Hidup. Jurnal Pangadereng Vol 5 (1). https:// doi.org/10.36869/.v5i1.21

Andayani Listyawati. (2016). Strategi Penanganan Kemiskinan Nelayan Tradisional. Jurnal Kemsos Vol 40 (1). https://doi.org/10.31105/mipks.v40i1.2284

Anta Maulana Nasution. (2020). Resesi Ekonomi, Pandemi, dan Kesusahan Nelayan. https://www.mongabay.co.id/2020/10/19/resesi-ekonomi-pandemi-dankesusahan-nelayan/)

Baum G, Januar HI, Ferse SCA, Kunzmann A. 2015. Local and regional impacts of pollution on coral reefs along the Thousand Islands north of the megacity Jakarta, Indonesia. PLoS ONE. 10 (9): e0138271.

Efrizal, R. (2020, April 24). Dampak COVID-19, Nelayan di Sumsel Jual Ikan dengan Harga Miring. Retrieved from https://sumsel.idntimes.com/news/sumsel/ muhammad-rangga-erfizal/dampak-covid-19-nelayan-di-sumsel-jual-ikandengan-harga-miring/4

Eriyatno. 1998. Ilmu Sistem Meningkatkan Mutu Dan Efektifitas Manajemen. Bogor: IPB Press.

Hastuty, Riany \& Adrianto, Luky \& Vitner, Yon. (2016). Kajian Manfaat Kawasan Konservasi Bagi Perikanan Yang Berkelanjutan Di Pesisir Timur Pulau Weh. Jurnal Teknologi Perikanan dan Kelautan. 6. 105. 10.24319/jtpk.6.105-116.

Kholil. 2005. Rekayasa Model Sistem Dinamik Pengelolaan Sampah Terpadu Berbasis Nirlimbah (Zero Waste). Studi Kasus di Jakarta Selatan (Disertasi). IPB. 
knti. (2020). Kondisi Sosial-Ekonomi Nelayan dan Pembudidaya di Masa Pandemi Covid-19. https://knti.or.id/kondisi-sosial-ekonomi-nelayan-dan-pembudidayadi-masa-pandemi-covid-19-2/) . .

Kusmuljono, B.S. \& Eriyatno, \& Marimin, Marimin \& Ariani, R.D.. (2007). The application of soft system methodology for agro-business micro-financing policy.

Ladwig N, Hesse KJ, Van der Wulp SA, Damar A, Koch D. 2016. Pressure on oxygen levels of Jakarta Bay. Mar Poll Bull. 110: 665-674.

Mardhia, D., Kautsari, N., Ilham Syaputra, L., Ramdhani, W., \& Okta Rasiardhi, C. . (2020). Penerapan Protokol Kesehatan dan Dampak Covid-19 Terhadap Harga Komoditas Perikanan dan Aktivitas Penangkapan. Indonesian Journal of Applied Science and Technology, 1(2), 80-87.

Mason, R.O and I.I. Mitroff. 1981. Challenging Strategic Planning Assumptions. John Wiley and Sons, New York.

Munir, Miftahul. (2020). Nelayan Tetap Melaut, Meski Harga Ikan Murah. https:// akurat.co/nelayan-tetap-melaut-meski-harga-ikan-murah

Nathan J. Bennett, Elena M. Finkbeiner, Natalie C. Ban, Dyhia Belhabib, Stacy D. Jupiter, John N. Kittinger, Sangeeta Mangubhai, Joeri Scholtens, David Gill \& Patrick Christie (2020): The COVID-19 Pandemic, Small-Scale Fisheries, and Coastal Fishing Communities, Coastal Management, DOI: 10.1080/08920753.2020.1766937

Palobo, Fransiskus \& Baliadi, Yuliantoro. (2019). Penerapan Interpretive Structural Modeling (ISM) Dalam Penentuan Elemen Pelaku Pengelolaan Tanaman Terpadu (PTT) Padi Sawah Menuju Pertanian Berkelanjutan Di Kabupaten Merauke. Jurnal Penelitian Pertanian Terapan. 19. 30. 10.25181/ jppt.v19i1.1396.

Ramadhan A, Maulana F, Rizky AW, Irwan M. 2016. Estimasi kerugian Nelayan dan Pembudidayaan Ikan Akibat Reklamasi di Teluk Jakarta. J Sos Kel Per .11(1): 1 $-11$

Ranny Rastati. (2020). Pandemi COVID-19 dan Nelayan: Menyoal Dampak pada Keberlanjutan Penghidupan, https://pmb.lipi.go.id/pandemi-covid-19-dannelayan-menyoal-dampak-pada-keberlanjutan-penghidupan/)

Robin, Rahmat Kurnia, Kadarwan Soewardi, Isdradjad Setyobudiandi, Arya H. Dharmawan. (2018). Analisis Mekanisme Adaptif Dan Kerentanan Nafkah Nelayan Di Teluk Jakarta (Studi Kasus: Nelayan Muara Angke, Kamal Muara dan Kalibaru). Sodality: Jurnal Sosiologi Pedesaan, Vol 6 (3), hal 212-219.

Saaty, T. L. (2012). Decision making for leaders: the analytical hierarchical process for decisions in a complex world. Pittsburg: RWS Publications

Sampono, Nono, A. Purbayanto, J. Haluan, A. Fauzi, B. Wiryawan. 2012. Dampak reklamasi Teluk Jakarta terhadap penangkapan ikan di Teluk jakarta. Disertasi. Sekolah Pascasarjana IPB. Bogor.

Saragih, S. H. (2013). Penerapan Metode Analytical Hierarchy Process (AHP) pada Sistem

Pendukung Keputusan Pemilihan Laptop. Pelita Informatika Budi Darma, IV(2).

Yasser Arafat, Mawardi Khairi. (2018). Kebijakan Larangan Penggunaan Alat Penangkapan Ikan Cantrang Dalam Perspektif Negara Hukum Kesejahteraan. Jurnal Borneo Vol 2 (2). https://doi.org/10.35334/bolrev.v2i2.724

Yudi Sutrasna,Ahmad Sugiono, Hendra. Wulan. A. M. (2020). Application of Analytical Hierarchy Process (AHP) in Determining Maritime Defense Strategy 